\title{
UNDERSTANDING THE IMPORTANT FACTORS INFLUENCING THE DEVELOPMENT OF ADOLESCENCE
}

\author{
By: St. Nurjannah Yunus Tekeng*
}

\begin{abstract}
Teori perkembangan remaja berfokus pada diskusi tentang perubahan-perubahan yang dialami oleh remaja dalam perkembangannya, yaitu perubahan biologis, psikologis, kognitif, dan sosial. Perubahan-perubahan ini mempengaruhi perkembangan perilaku remaja. Pada periode ini, remaja mengalami krisis identitas (identity crisis) dimana mereka mempertanyakan status keberadaan mereka di tengah masyarakat. Pada proses pencarian jati diri ini, kebutuhan akan penghargaan yang positif terhadap diri mereka (positive self-esteem) menjadi sangat penting karena hal itu dapat membantu mereka beradaptasi dengan tekanan dari kelompok sebaya (peer pressure). Perkembangan remaja juga sangat dipengaruhi oleh lingkungan langsung mereka (immediate environment) dalam hal ini kelompok sebaya (peer group) disaat mereka meninggalkan rumah dan bergabung dengan kelompok tersebut.
\end{abstract}

KEYWORDS: Adolescence, developmental changes, influence, peer group, self-esteem

ADOLESCENCE is an important stage in human development. It is the phase when very rapid changes take place both physically and psychologically. It is the stage which serves as the link between childhood and mature adulthood. The word adolescence means to "grow up". This growing up is a process in every sense that is to grow up to accomplish a number of developmental tasks, adolescences also have to adjust to the changes in their body. These body changes trigger off a psychological revolution as well. They realizes that they are no longer a child and yet not an adult. What the growing adolescences experience and feel? How they cope with the bodily changes? Why they behave the way they do, and what are some of their psychological characteristics? These are some of the questions which will help us to understand.

${ }^{*}$ The author got her undergraduate from teaching English as a second language department of Tarbiyah Faculty of IAIN Alauddin Makassar, and than she furthered her study at Faculty of Education The Flinders University of South Australia, Adelaide, South Australia. 
In addition, adolescences also experiencing changes in their thinking process. Each of these changes contribute to adolescences' behavior. Adolescences need to adapt this changes successfully. Failure to go through this will lead to maladapted behavior. Therefore, it is very important to understand the development of adolescences in order to help them going through this period safely.

Based on the description above, the writer formulates the following questions: What is the concept of adolescence? What developmental changes faced by adolescence? How important is the self-esteem for adolescence? And, What is the role of peer group in adolescence's life?

The paper aims to explain the important factors influencing the development of adolescences using the concept of developmental theory. In addition, The understanding of adolescent development could be very important for parents and teacher in order to help them going through this critical period toward adulthood.

\section{DEVELOPMENTAL THEORY OF ADOLESCENCE}

Based on this theory, the discussion will be focused on the issues related to adolescence. They are, the definition and concept of adolescence, the development of self-identity and self-esteem, and the relationship with peers.

\section{The Concept of Adolescence}

Adolescence is derived from the Latin word "adolescere", which means "to grow into adulthood". ${ }^{1}$ It is defined as the period of rapid changes both biologically and psychologically. ${ }^{2}$ Biologically, the adolescence period is marked by the onset of puberty, that is the development of bodily changes. ${ }^{3}$ Psychologically, it is the changes in the individual's emotion, motivation, behavior, and the individual's relation with others. ${ }^{4}$ Social scientists differentiate this into three adolescence periods, namely early adolescence that covers the period from age 11 through age 14, middle adolescence from about age 15 through age 18, and late adolescence from about age 18 through the age 21. This division corresponds to the way in which the society groups young people in educational institution; they are the approximate ages of middle, junior high, high school, and college. ${ }^{5}$

During this period, adolescences are experiencing an identity crisis ${ }^{6}$, where the individuals are trying to come to terms with themselves and their environment. ${ }^{7}$ Adolescences will question themselves with the "who am I?" question. In addition, adolescence is also a period of the development of behavioral and emotional autonomy. ${ }^{8}$ 


\section{Adolescence Developmental Changes}

As mentioned before that in adolescences' life span they are experiencing some developmental changes. They are biological, cognitive, social, and psychological development.

\section{Biological Development}

Biologically, adolescences are experiencing puberty which is defined as the biological changes of adolescence. Biological developments change boys and girls from physical immaturity to biological maturity. These changes on adolescences have critical impact on their development as they are not only result in sexual changes, but also in psychological and emotional changes. According to Geldard and Geldard, Puberty in adolescences happens at different ages and different rates. Consequently, 'there may be issues for adolescences who may feel embarrassed, selfconcious, akward and out of step with peers who are developing at a different rate. Therefore, it is not surprising that many adolescences become very anxious about their appearance. ${ }^{9}$ Furthermore, Steinberg stated 'physical and sexual maturation profoundly affect the way in which adolescents view themselves and the way in which they are viewed and treated by others. Yet the social environment exerts a tremendouse impact on the meaning of puberty and its psychological and social consequences'. ${ }^{10}$

\section{Cognitive Development}

Concerning with the cognitive development of adolescence, at this period according to Gerald and Gerald ${ }^{11}$, Adolescences are experiencing some changes in their thinking process. First, they develop a capacity for abstract thinking. Second, they discover how to think about relationship issues. Third, they discern new ways of processing information. Fourth, they learn to think creatively and critically. In addition, adolescences are egocentric that they see themselves as a unique person.

\section{Psychological Development}

The psychological changes appear in the areas of emotional and moral development. During adolescent period, individual is at faces a very wide range and variety of emotions. These include both positive and negative emotions. Happiness is as joy, exuberance exhilaration etc. and sadness is as depression, unhappiness, anxiety, fear, lorry etc. In addition, of anger, rebellion and protest also emerge. Interestingly, patriotism, and sacrifice for the nation also develop. Each of these emotions is felt very 
intensely. In fact, the strength and intensity of adolescent emotion is one of their prominent characteristics. They tend to express everything in a very exaggerated form.

In the moral sphere too, adolescences undergo very prominent changes. They now develop a firm sense of ethics or an understanding of what is right and wrong. This is based not only on what their parents and elders have taught them, but on they own experience as well. They also begin to question certain social and moral codes prevalent in society and accepts only those which they are convinced about. Their eagerness to be a nice-boy or nice girl and please others ceases to be important now. It gets replaced by their questioning mind and conviction about what they are doing. They begin to understand the importance of law in maintaining order in society. Further, adolescences begin to evolve a set of personal values which become the guiding principles of their life.

\section{Social Development}

The social development of adolescences can be seen in ways where they separate themselves from their parents and move towards their peer groups. Therefore, peer group becomes the social agent for adolescences to search for personal identity. As stated by Geldard and Geldard ${ }^{12}$ that the process of socialization occurs at the same time as the search for identity. In addition, concerning with this adolescent's conformity to their peer group will increase.

In early adolescence, they tend to form close relationship with friends of the same sex, but this tendency then changes when they move to mid and late adolescence that they tend to build up relationship with their opposite sex.

\section{Adolescent Self-Esteem}

The literature reveals that positive self-esteem serves as a buffer against stress and is typically associated with a wide range of productive coping strategies. In addition, it is clearly linked with motivation and positive emotional states. In contrast, individuals with low self-esteem are more at risk for emotional and behavioral disorders such as anxiety, depression, and lack of motivation or energy. Behavioral manifestations can frequently be seen in suicidal tendencies, delinquency, conduct problems, and eating disorders. ${ }^{13}$ In addition, Kaplan ${ }^{14}$ reported that there is a strong relationship between having negative self-attitude and the adoption of deviant behavior such as delinquency, criminality, drug use , drinking alcohol and aggressive behavior. 
Self-esteem is a feeling of self-worth. ${ }^{15}$ It refers to "a sense of acceptance, a personal liking for oneself, and a form of proper respect for oneself". ${ }^{16}$ Self esteem is also defined by Kaplan ${ }^{17}$ as "the need of the person to maximize the experience of positive self-attitudes or self-feelings and to minimize the experience of negative self-attitude". Kaplan further explained that positive self-attitudes refer to by many terms such as feelings of self-respect, worth, approval, regard, acceptance as well as esteem, whereas negative self-attitudes are feelings of self-derogation, rejection, and hate.

For adolescences, having high self-esteem is of great importance since they may undergo an identity crisis during this period of the life span. Furthermore, they are expected to behave as young adults and not as children anymore. Therefore, the need for self-respect, acceptance, approval, and regard will be very significant for them. One of the determinants of experiencing positive self-esteem is the quality of their relationship with their parents and peers. ${ }^{18}$ How they perceive, feel, and evaluate themselves is based on the attitude of parents and peers toward them. In addition, how they perceive and interpret their parents and peers' behavior toward them is determined by how much value they put on them. ${ }^{19}$ Therefore, those who are rejected, excluded, ignored, or ridiculed by their parents or peers on whom they put high value, are likely to experience negative self-attitude or self-feeling. ${ }^{20}$ For example, adolescences have a strong desire for autonomy in that they want to become individuals in their own right, express their own ideas, and live uniquely theirs. Therefore, parents who realize such desire and respect it as such, and actively encourage the quest for autonomy will enhance adolescents' positive self-feeling so that they become and feel more self-sufficient in doing things such as making their own decisions. ${ }^{21}$ However, if parents ignore this desire, adolescences are more likely to experience feeling of worthlessness, which in turn may result in low self-esteem.

The necessity for adolescences to have high self-esteem is because it may affect their adjustment to peer pressure. In this case, the role of parents is very important. As stated by Epstein 22 :

Parents should build up their children's self-esteem at a very early age. Youngsters with a good self-image will almost always seek out membership in more socially acceptable groups. Children who grow up with little or no self-confidence stand a greater chance of getting mixed up with anti social peer groups. These adolescences think of themselves as losers and only find acceptance in groups where other teens also feel negative about themselves".

The fact that adolescences tend to attach great importance to the attitude and opinion of others who are in their own ages 23 is significant, 
therefore, those who are rejected, disapproved, or isolated by their peers are more likely to experience low self-esteem. They may feel that they do not have any status among their peer group. This can be due to their poor achievement at school, having an ugly body shape if the group is based on this characteristic especially girls, being in a low social-economic status, or having few or no friends. As Harter ${ }^{24}$ stated, the individual who has no competence in the domains in which they desire to improve, such as being socially unacceptable by peers, are likely to result in low self-esteem. One of the consequences of having low self-esteem for adolescences, is that they may adopt deviant behavior by engaging with deviant groups as a compensation for their inadequate self-concept and their self-rejecting feelings. 25

\section{Adolescents and their Relation with Peers}

As children grow up they come to the period of being adolescents. In this period, their attachment to parents becomes more distant physically and psychologically. This can be seen as a decrease in emotional closeness and warmth. At the same time, their involvement with peers becomes stronger. ${ }^{26}$ For adolescences, the peer group is the most important context in which the learning and reinforcement of values and behaviors take place. Peers play an important role in their psychological development because peers can give them support for two primary developmental tasks. Firstly, identity, that is helping adolescences to clarify their personal identity 27 , or finding the answer to the question "who am I?". Secondly, autonomy, that is, discovering the self as separate and independent from parents. ${ }^{28}$ In addition to that, Conger ${ }^{29}$ stated that the peers provide "the opportunity to learn how to interact with age-mates, to control social behavior, to develop age-relevant skills and interests, and to share similar problems and feelings".

Based on the significant function of the peer group for adolescent development, the need for status and acceptance from their peers is crucial. One element that reflects the approval or acceptance, in adolescent society, is the number of friends they have. Therefore, to be part of a leading crowd, that is, a group which is formed based on personal attitude, interest, or abilities, may become crucial for them, for status and friends. In addition, it also affects the way they see themselves. In contrast, being an outsider of a leading crowd may result in negative self-evaluation. Furthermore, those who have neither status in the social system a whole, nor the support of a set of friends will keep seeking their status elsewhere rather continuing to hold the negative image about themselves. In these circumstances, 
adolescences may have a possibility to engage with a deviant group who offers them member status in the group. ${ }^{30}$ This in turn, will give adolescences more possibilities to be involved in deviant or aggressive behaviors. As stated by Henggeler ${ }^{31}$ adolescences association with delinquent peers can contribute to deviant behavior. This statement is supported by a finding from a study conducted by Cheung 32 that the more deviant behavior committed by friends, the more likely adolescences involve in deviant behaviors as well. Hence, some scholars conclude that modelling and social approval for delinquent acts are the two process that determine the adoption of delinquent behavior ${ }^{33}$.

Horrocks ${ }^{34}$ explained that in a peer culture, it is not that simple for adolescences to be accepted by their peers. They need to do something that can satisfy the group or they have to conform to the normative expectation shared by the group ${ }^{35}$. Failure to do this will result in being excluded, rejected, and isolated. This demand from the group then is recognized as peer pressure. Some studies have found that peer pressure is very powerful in driving and forcing adolescences to delinquent or aggressive behavior. For example Dupre, Miller, Gold, and Rospenda ${ }^{36}$ found in their study that $84 \%$ of adolescences who tried drugs did so as a result of their peer pressure. Newman and Newman ${ }^{37}$ argued that "there are demands from within the group to conform to the norms of the group and to demonstrate commitment and loyalty to the other group members". The attempts of a group to control the behavior of its members by threatening unpleasant consequences combined with the fear of rejection and ridicule from the members of the group are two powerful conditions that can ensure that all the members of the group are to "toe the line". ${ }^{38}$ Therefore, it is not surprising that adolescences who engage with a deviant or aggressive peer groups are more likely to be involved in a deviant or aggressive behavior as they are afraid of being ridiculed if they reject involvement in deviant behavior (e.g. drug use) or they are afraid of losing their membership status from the group.

Moreover, For some adolescences to gain acceptance and status in the peer group is very important. Therefore, within the group setting they sometimes lose their sense of self-awareness. They become aggressive without considering the rightness or wrongness of their acts and what can be the negative consequences. This process is called as "deindividuation". 39 According to Geen ${ }^{40}$ there is a strong relationship between aggressive behavior and deindividuation. The deindividuated individuals, who lose the sense of identity, are stimulated by the fear of social disapproval. ${ }^{41} \mathrm{In}$ addition, Diener ${ }^{42}$ explained how groups function to draw on individual's attention away from the self to the direction of external stimuli. In this 
stage, individuals are more controlled by cues of the immediate situations rather than by their personal and social standards.

In relation to the identity crisis and in the formulation of self-concept, adolescences are extremely vulnerable to judgments expressed by those in the immediate environment because the individuals is at period in their life where others opinions are of tremendous importance. Strang in Rice ${ }^{43}$ has outlined four basic dimensions of the self. One of them is the adolescents' social selvess. In this case, how others think and see of themselves, in turn influence how they think of themselves. Since adolescences spend most of their awaking time with their peers and develop great attachment to them as stated by Brown ${ }^{44}$ that high school students spend twice as much of their time with peers as with parents or other adults, therefore, peers is regarded as their immediate environment. It is not surprising, then, if adolescences tend to be stimulated by their peers' behavior. Moreover, peers not only can influence adolescences to positively develop their selfconcept, but they can also influence adolescences to negatively develop their self-concept as well. Therefore, while searching for self identity in adolescence, it is possible that they can be misled by their peers, especially those who are highly involved in delinquent and aggressive behavior.

\section{CONCLUSION}

To sum up, Adolescence period is a very critical period in human life. This is characterized by many changes faced by young persons and each of them will contribute to their behavioral development. As they move away from family toward their peer group, this due to searching for their personal identity which also means that adolescences are trying to clarify who they are and are trying to fit their position in the society. During this process, experiencing positive self-steem is very crucial for adolescences since they need to adjust to peer pressure that they may experience when they are involved in a peer group as their immediate environment.

\section{END NOTES:}

1. Eastwood. Atwater, Adolescence, New Jersey: Prentice-Hall Inc. 1983.

2. J. Lipsitz, Growing up Fotgotten, Lexinto: D.C. Health and Company, 1977.

3. A. Hargreaves, and L. Earl, Rights of Passage: A review of Selected Resaerch about Schooling in the Transition Years. Ontario Ministry of Education: Toronto, 1990.

4. L. Steinberg, Adolescence, New York: Alfred A. Knopf, 1985.

5. L. Steinberg, Adolescence, New York: Alfred A. Knopf. P. 7.

6. E. H. Erikson, Identity: Youth and Crisis. London: Faber \& faber, 1968.

7. J. E. Horrocks, The Psychology of Adolescence, Boston : Houghton Mifflin,1976. 
8. E. Atwater, Adolescence, New Jersey: Prentice-Hall Inc.

9. K. Geldard, dan D. Geldard, Counselling Adolescents. London: SAGE Publications, 1999.

10. Laurence Steinberg, Adolescence, New York: Alfred A. Knopf, p. 24

11. K. Geldard, dan D. Geldard, Counselling Adolescents. London: SAGE Publications, p. 4.

12. K. Geldard, dan D. Geldard, Counselling Adolescents. London: SAGE Publications, p. 9.

13. Susan Harter, Causes and Consequences of Low Self-Esteem in Children and Adolescents. In Self-Esteem: The Puzzle of Low Self-Regard edited by R. F. Baumeister, New York: Plenum Press, 1993.

14. Howard, B. Kaplan, Self Attitude and deviant behavior, California: Goodyear Publishing Company Inc., 1975.

15. Susan Harter, Causes and Consequences of Low Self-Esteem in Children and Adolescents. In Self-Esteem: The Puzzle of Low Self-Regard edited by R. F. Baumeister, New York: Plenum Press, p. 88.

16. G. R. Adams dan T. Gullotta, Adolescent Life experience (2nd Ed). California: Brooks/Cole Publishing Company, 1989.

17. Howard, B. Kaplan, Self Attitude and deviant behavior, California: Goodyear Publishing Company Inc., p.10.

18. G. R. Adams dan T. Gullotta, Adolescent Life experience (2nd. Ed). California: Brooks/Cole Publishing Company.

19. Howard. B. Kaplan, Self Attitude and deviant behavior, California: Goodyear Publishing Company Inc.

20. Howard,B. Kaplan, Self Attitude and deviant behavior, California: Goodyear Publishing Company Inc.

21. Eastwood Atwater, Adolescence, New Jersey: Prentice-Hall Inc.

22. B. A. Epstein, The Important of Peer Pressure (On-line), available at: http:// www.alkids.org/Epstein/articles/peer-pressure.html, 1999.

23. James. S. Coleman, The Adolescent Society: The Social Life of Teenagers and its Impact on Education. New York: Collier- Mcmillan Company, 1961

24. Susan Harter, Causes and Consequences of Low Self-Esteem in Children and Adolescents. In Self-Esteem: The Puzzle of Low Self-Regard edited by R. F. Baumeister, New York: Plenum Press, p. 91.

25. F. Philip Rice, The adolescent: Development, Relationship, and Culture (7th.Ed). Boston: Allyn and Bacon, 1992.

26. H. G. Lingren, Adolescence and Peer Pressure (On-line) available at: http:// www.ianr.unl.edu/pubs/nebfact/nf211.htm, 1999.

27. Eastwood Atwater, Adolescence, New Jersey: Prentice-Hall Inc.

28. H. G. Lingren, Adolescence and Peer Pressure (On-line) available at: http:// www.ianr.unl.edu/pubs/nebfact/nf211.htm.

29. J. J. Conger, Adolescence and Youth: Psychological Development in a changing World. New York : Harper \& Row, Publishers, 1973, p.286.

30. James S. Coleman, The Adolescent Society: The Social Life of Teenagers and its Impact on Education. New York: Collier-Mcmillan Company, 1961.

31. Scott W. Henggeler, Delinquency in Adolescence. Newbury Park London: sage Publication Vol.18 Developmental Clinical Psychology and Psychiatry, 1989. 
32. Y. W. Cheung, Family, School, Peer, and Media Predictors of Adolescent Deviant Behavior in Hong Kong. Journal of Youth and Adolescence. Vol. 26, No. 5, 1997, p. 580.

33. Scott W. Henggeler, Delinquency in Adolescence. Newbury Park London: sage Publication Vol.18 Developmental Clinical Psychology and Psychiatry, p. 50.

34. John E. Horrocks, The Psychology of Adolescence. Boston: Houghton Mifflin, 1976.

35. Howard B. Kaplan, Self Attitude and deviant behavior, California: Goodyear Publishing Company Inc.

36. D. Dupre, N. Miller, M. Gold, and K. Rospenda, Initiation and Progression of Alcohol, Marijuana, and Cocaine Use Among Adolescent Abuser. American Journal on Addiction, 4 (1), 1995, 43 - 48.

37. P. R. Newman, and B. M. Newman, Early Adolescence and its Conflict: Group Identity vs. Alienation. Adolescence: 11, 1976, p. 267.

38. James S. Coleman, The Adolescent Society: The Social Life of Teenagers and its Impact on Education. New York: Collier- Mcmillan Company.

39. Russel G. Geen, Human Aggression. Milton Keynes: Open University Press, 1990.

40. Russel G. Geen, Human Aggression. Milton Keynes: Open University Press.

41. P. G. Zimbardo, The Human Choice; Individuation, Reason, and Order Versus Deindividuation, Impulse, and Chaos. Nebraska Symposium on Motivation: 17, 1970.

42. E. Diener, Deindividuation: The Absence of Self-Awareness and Self-Regulation in Group Members. In P. B. Paulus (Ed.), The Psychology of Group Influence. HillsDale, N. J: Erlbaum, 1980.

43. F. Philip Rice, The adolescent: Development, Relationship, and Culture (7th.Ed). Boston: Allyn and Bacon, p. 247.

44. B. B. Brown, Peer Groups and Peer Cultures. In S. S. Feldman, and G. R. Elliot (eds). At the Threshold. Cambridge : Harvard University Press, 1990.

\section{BIBLIOGRAPHY}

Adams, G. R., \& Gullotta, T., Adolescent Life experience ( $2^{\text {nd }}$. Ed), California: Brooks/ Cole Publishing Company, 1989.

Atwater, E., Adolescence, New Jersey: Prentice-Hall Inc., 1983.

Brown, B. B., Peer Groups and Peer Cultures, In S. S. Feldman, and G. R. Elliot (eds). At the Threshold, Cambridge : Harvard University Press, 1990.

Cheung, Y. W., Family, School, Peer, and Media Predictors of Adolescent Deviant Behavior in Hong Kong, Journal of Youth and Adolescence, Vol. 26, No. 5, 1997.

Coleman, J. S., The Adolescent Society: The Social Life of Teenagers and its Impact on Education, New York: Collier- Mcmillan Company, 1961.

Conger, J. J., Adolescence and Youth: Psychological Development in a changing World, New York : Harper \& Row, Publishers, 1973.

Diener, E., Deindividuation: The Absence of Self-Awareness and Self-Regulation in Group Members, In P. B. Paulus (Ed.), The Psychology of Group Influence, Hills-Dale, N. J: Erlbaum, 1980. 
Dupre, D., Miller, N., Gold, M., Rospenda, K., Initiation and Progression of Alcohol, Marijuana, and Cocaine Use Among Adolescent Abuser, American Journal on Addiction, 4 (1) 1995.

Epstein, B. A., The Important of Peer Pressure (On-line), available at: http://www. alkids.org/Epstein/articles/peer-pressure.html, 1999.

Erikson, E. H., Identity: Youth and Crisis, London: Faber \& faber, 1968.

Geen, R. G., Human Aggression., Milton Keynes: Open University Press, 1990.

Geldard, K., \& Geldard, D., Counselling Adolescents, London : SAGE Publications, 1999.

Hargreaves, A., and Earl, L., Rights of Passage: A review of Selected Resaerch about Schooling in the Transition Years, Ontario Ministry of Education: Toronto, 1990.

Harter. S., Causes and Consequences of Low Self-Esteem in Children and Adolescents, In Self-Esteem: The Puzzle of Low Self-Regard edited by R. F. Baumeister, New York: Plenum Press, 1993.

Henggeler, Scott W., Delinquency in Adolescence, Newbury Park London: sage Publication Vol.18, Developmental Clinical Psychology and Psychiatry, 1989.

Horrocks, J. E., The Psychology of Adolescence, Boston : Houghton Mifflin, 1976.

Kaplan, H. B., Self Attitude and deviant behavior, California: Goodyear Publishing Company Inc., 1975.

Lingren, Herbert. G., ) Adolescence and Peer Pressure, (On-line) available at: http:/ / www.ianr.unl.edu/pubs/nebfact/nf211.htm, 1999.

Lipsitz, J., Growing up Fotgotten, Lexinto: D.C. Health and Company, 1977.

Newman, P. R., \& Newman, B. M., Early Adolescence and its Conflict: Group Identity vs. Alienation. Adolescence: 11, 1976.

Rice, F. P., The adolescent: Development, Relationship, and Culture (7 ${ }^{\text {th }}$.Ed), Boston: Allyn and Bacon, 1992

Steinberg, L., Adolescence, New York: Alfred A. Knopf., 1985.

Zimbardo, P. G., The Human Choice; Individuation, Reason, and Order Versus Deindividuation, Impulse, and Chaos, Nebraska Symposium on Motivation: 17, 1970.

UNDERSTANDING THE IMPORTANT FACTORS (ST. NURJANNAH YUNUS TEKENG) 257 